\title{
The Effects of Sodium Percarbonate Generated Free Oxygen on Daphnia-Implications for the Management of Harmful Algal Blooms
}

\author{
Robin Thoo ${ }^{1}$, Waldemar Siuda ${ }^{2}$ and Iwona Jasser ${ }^{1, *}$ \\ 1 Institute of Environmental Biology, Faculty of Biology, Biological and Chemical Research Centre, \\ University of Warsaw, 02-089 Warsaw, Poland; r.thoo@student.uw.edu.pl \\ 2 Institute of Functional Biology and Ecology, Faculty of Biology, Biological and Chemical Research Centre, \\ University of Warsaw, 02-089 Warsaw, Poland; w.siuda@biol.uw.edu.pl \\ * Correspondence: jasser.iwona@biol.uw.edu.pl
}

Received: 30 March 2020; Accepted: 1 May 2020; Published: 5 May 2020

\begin{abstract}
Increasing frequencies and durations of harmful algal blooms are a nuisance in many aquatic ecosystems. This has led to the use of a variety of control methods to prevent their appearance or to disperse them following their establishment. Most of these methods are not selective; consequently, research into alternative selective methods has been ongoing. Reactive oxygen species generated following the addition of hydrogen peroxide have been shown to selectively target the cyanobacterial component of harmful algal blooms in experimental and field settings. This study assesses the effects of increasing concentrations of reactive oxygen species from the addition of sodium percarbonate on zooplankton in a small experimental setting using a natural plankton sample. It was found that the genus Daphnia showed moderate sensitivity to sodium percarbonate. Preliminary evidence suggests that the size of an individual may affect the probability of survival, with larger individuals having a lower likelihood of survival. Lower survival rates of large Daphnia were hypothesized to have been caused by higher relative filtration rates of larger individuals. From the zooplankton data obtained, we suggest that a safe concentration of sodium percarbonate for Daphnia individuals would be below $10.0 \mathrm{mg} \cdot \mathrm{L}^{-1}$ sodium percarbonate $\left(2.8 \mathrm{mg} \cdot \mathrm{L}^{-1}\right.$ hydrogen peroxide $)$.
\end{abstract}

Keywords: eutrophication; cyanobacteria; Daphnia; harmful algal bloom mitigation; phytoplankton; zooplankton; reactive oxygen specie

\section{Introduction}

Phytoplankton forms the base of the aquatic pelagic food web [1]. These photosynthetic organisms are a key component of freshwater aquatic ecosystems, and the majority of other aquatic environments [2]. Algae is a broad term that encompasses a wide range of organisms, some of which, due to increasing levels of pollution (among other factors) are the primary contributors to eutrophication. Eutrophication is undesirable for water bodies for a number of reasons, ranging from ecological and economic concerns to pure aesthetics [3]. It is not the only phytoplankton component that causes blooms to be a nuisance, but the proliferation of cyanobacteria are a particular cause of concern because of the large number of negative effects that can result when their abundance becomes too high. Such issues include but are not limited to: shading and outcompeting other phytoplankton species and macrophytes, interfering with large zooplankton feeding by clogging and providing poor quality food, forming scum on water surfaces, and eventually producing toxins which may be harmful for other organisms and humans [3-8]. Owing to the mixed or heterogeneous community of organisms within a fluid medium (notwithstanding stratification due to temperature, light and temperature gradients, and so on) a major complication in combatting harmful algal blooms (HABs), and an even 
greater problem in combatting the cyanobacterial component, is that of targeting a specific organism or group of organisms. This becomes more complex when we consider that cyanobacteria can be found not only as large colonies and scum, easily visible to the naked eye, but also as individual cells or clusters of cells (filaments and small colonies) dispersed within a varied algal community. Moreover, this varied algal community shares living space with numerous other biological entities from viruses to zooplankton to large, complex eukaryotes such as planktivorous and predatory fish, with each entity having the possibility of responding in undesirable or unexpected ways to any attempt made to mitigate a HAB.

Long-term preventative solutions are the primary goal of combatting eutrophication and of reducing the impact of $\mathrm{HABs}$, with the restoration of water bodies to pristine or near pristine conditions via the reduction of nutrient inputs and regression to the former hydrological regime being the ideal endpoint [9]. Unfortunately, this is often not possible or takes a long time. Therefore, a large number of physical and chemical methodologies have been devised to provide short-term relief to affected bodies of water. The addition of chemicals has proven useful, with algaecides such as copper sulphate being particularly effective, but many such chemicals leave traces in the environment and cannot discriminate between organisms, with negative effects having been observed on all levels of the trophic chain $[10,11]$.

Reactive oxygen species (ROS) are forms of oxygen with at least one unpaired electron and are therefore highly reactive, since atoms and molecules will 'seek' to return to an electrically neutral state. In essence they are a form of free radical with a high oxidative potential, and often cause chain reactions which damage biological molecules. Microscopic planktonic primary producers such as eukaryotic algae and cyanobacteria differ in their abilities to tolerate ROS as a result of different photosynthetic paths. Therefore, the addition of chemicals that generate ROS has been suggested as an effective tool to selectively remove cyanobacteria [12].

In eukaryotic algae and plants, ROS are continually produced as byproducts of various metabolic pathways localized in different cellular compartments. Under steady state conditions these byproducts are scavenged by anti-oxidative defense components to minimize possible oxidative damage, but this equilibrium can be disrupted [13]. Eukaryotic algae and plants also synthesize numerous oxidises and peroxidises in response to environmental changes. Within plants and eukaryotic algae, hydrogen peroxide (HP) is often created under natural conditions of high light. It is a waste product produced during the processes used to deal with surplus photons in the electron sinks associated with elevated photosynthesis [14].

In contrast, because of the flavoproteins flv1 and flv3 present in cyanobacteria, superoxide is not formed as part of the mechanisms used to deal with high light levels, thus cyanobacteria do not produce ROS internally in a Mehler-like reaction and so neither have nor need the same coping mechanisms to deal with their presence. It has been demonstrated, both experimentally in the laboratory and in the field, that at low doses ROS may have selectivity for the cyanobacteria within HABs because of the above [9]. Consequently, a large number of studies have been conducted using HP to generate ROS with the intention of targeting cyanobacteria while reducing the relative impact on other organisms. Hydrogen peroxide has the benefit of not only being readily available to facilitate the creation of ROS, but it also decays to water and oxygen within a maximum period of a few days $[15,16]$. Additionally, it is not considered to be carcinogenic [4] and it is a commonly encountered component of the aquatic environment [12], with typical concentrations in lakes of $1-30 \mu \mathrm{g} \cdot \mathrm{L}^{-1}$ [15].

Far fewer studies are available on functionally similar compounds such as sodium percarbonate (SP), which decomposes in water to form sodium, carbonate and HP [16]. The main difference between these compounds is that the carbonate portion of SP can cause an increase in alkalinity and pH which depends on the buffering capacity of the water to which it is added [17].

$$
\begin{gathered}
2 \mathrm{Na}_{2} \mathrm{CO}_{3} \cdot 3 \mathrm{H}_{2} \mathrm{O}_{2} \rightarrow 3 \mathrm{H}_{2} \mathrm{O}_{2}+4 \mathrm{Na}^{+}+2 \mathrm{CO}_{3}{ }^{2-} \\
2 \mathrm{H}_{2} \mathrm{O}_{2} \rightarrow 2 \mathrm{H}_{2} \mathrm{O}+\mathrm{O}_{2}
\end{gathered}
$$


Interactions between the cyanobacterial component of phytoplankton, zooplankton and larger organisms such as fish are crucial to the understanding, maintenance and management of aquatic ecosystems and as a result have been widely studied [18]. Macroinvertebrates and zooplankton in particular are the main components of most pelagic food webs and are the major herbivores in freshwater lakes and ponds [19-21]. Aquatic macroinvertebrates have been shown to differ in sensitivity to changes in the physicochemical parameters of water and various toxic compounds [22]. In natural waterbodies, the $\mathrm{pH}$ fluctuates due to the photosynthetic activity of algae and the respiration of aquatic animals, varying daily between 7 and 9 [23]. Pedersen and Hansen [24], studying the marine plankton community, found that increases of $\mathrm{pH}$ above 9 induce unfavorable changes in the zooplankton community, while Yin and Niu [25] found that in experimental conditions, age-specific survival curves were not significantly different within five of the studied Brachionus rotifer species between $\mathrm{pH}$ values of 6 and 10. Among freshwater macroinvertebrates, Daphnia seems to be one of the most vulnerable species to decreases in $\mathrm{pH}$. While fewer studies exist on $\mathrm{pH}$ increases, Beklioglu and Moss [26] found that increasing $\mathrm{pH}$ through the addition of $\mathrm{NaOH}$ did not negatively affect D. hyalina up until $\mathrm{pH} 11$, and suggest an upper limit of approximately $\mathrm{pH} 10.5$ to 11 for Cladocera survival. Taking this into account, sodium percarbonate increasing the alkalinity of water may begin to negatively influence zooplankton if the $\mathrm{pH}$ begins to rise above $\mathrm{pH} 9$.

The aim of this investigation was therefore to gain a preliminary understanding of the possible effects of SP on the genus Daphnia, the keystone species in temperate freshwaters and thus one of the most commonly studied mesozooplankton [21,27], in controlled conditions using pond water with a natural plankton assemblage. If ROS generated from this substance are to be widely used to treat HABs, the possible effects on non-target organisms need to be established to facilitate making appropriate management decisions. It should be pointed out that Daphnia, especially large Daphnia, contribute significantly to the maintenance of clear water through filter feeding, in line with McQueen et al.'s [28] model of top-down control of phytoplankton. According to Christoffersen et al. [29], large Daphnia may prevent cyanobacteria from blooming, and therefore may strengthen the effect of SP on the aquatic community. A level of certainty is required so that the technologies used to maintain and protect ecosystem services, including the use of ROS, exert only a minimal amount of stress or damage on non-target organisms and do not negatively affect top-down control of algal growth.

\section{Materials and Methods}

A microcosm experiment was conducted where SP was added to ten plastic containers, each with 1 liter of lake water and approximately the same number of individual planktonic crustaceans. Water samples were collected on the 15 th of May from the surface layer $(0.5 \mathrm{~m})$ of a shallow artificial lake (0.35 ha) with a maximum depth of $1.8 \mathrm{~m}$ and a mean depth of $1.4 \mathrm{~m}$ located in Dawidy Bankowe, a village in the Mazovian Voivodeship, Poland ( $\left.52^{\circ} 07^{\prime} 0753^{\prime \prime} \mathrm{N}, 20^{\circ} 59^{\prime} 43.09^{\prime \prime} \mathrm{E}\right)$. In mid-April the lake was characterized by the following physiochemical characteristics: $\mathrm{pH}-8.1 ; \mathrm{NH}_{4}^{+}-0.510 \mathrm{mg} \cdot \mathrm{L}^{-1}$; $\mathrm{P}_{-} \mathrm{PO}_{4}{ }^{3-}-0.046 \mathrm{mg} \cdot \mathrm{L}^{-1} ; \mathrm{DOP}-0.005 \mathrm{mg} \cdot \mathrm{L}^{-1}$; DOC-12.7 $\mathrm{mg} \cdot \mathrm{L}^{-1}$ and Chlorophyll a-83 $\mu \mathrm{g} \cdot \mathrm{L}^{-1}$. At the time of sample collection for the experiment in May, the temperature of water was $17^{\circ} \mathrm{C}$ and the phytoplankton biomass obtained by microscopic analysis was just over $3.0 \mathrm{mg}$ fresh weight $\mathrm{L}^{-1}$. Phytoplankton was dominated by Cryptophyceae and Chlorophyceae, with Cyanobacteria accounting for only about 3\% of total phytoplankton biomass. In the laboratory the water sample was poured into a large mesocosm, from which the 1 liter experimental sub-samples were obtained. To ensure that approximately the same number of planktonic crustaceans were present in each treatment, the mesocosm was mixed slowly to ensure homogeneity and then 1 liter of lake water was extracted.

Three of the containers were set as controls and seven containers contained increasing concentrations of SP $\left(5,10,20,30,40,50\right.$ and $\left.60 \mathrm{mg} \cdot \mathrm{L}^{-1}\right)$. This kind of experimental design (three controls and a gradient experimental treatment) was chosen to ensure that the Daphnia which had been transferred to the mesocosms were not adversely affected under the base conditions of the experiment, allowing us to confidently attribute mortality to SP in the treatments along a gradient of increasing SP 
concentration. The SP was manufactured to a technical grade by envolab.pl (Długomiłowice, Poland) $\left(2 \mathrm{Na}_{2} \mathrm{CO}_{3} \cdot 3 \mathrm{H}_{2} \mathrm{O}_{2}\right.$ [30]). According to the manufacturer, the maximum solubility of the SP in water at $20{ }^{\circ} \mathrm{C}$ was $120 \mathrm{~g} \cdot \mathrm{L}^{-1}$, giving a HP solution of approximately $3.2 \%$. The addition of SP to lake water with $\mathrm{pH} 8.1$ caused an increase of the $\mathrm{pH}$ to 8.4 at $60 \mathrm{mg} \cdot \mathrm{L}^{-1} \mathrm{SP}$ and 9.7 at $300 \mathrm{mg} \cdot \mathrm{L}^{-1} \mathrm{SP}$ (Supplementary Material Figure S1). Trace iron content was no greater than 15 ppm, with a minimum active oxygen content of $13 \%$. To facilitate comparison of the results with studies using HP, information on the breakdown of SP to HP in water solutions is given in Table 1 and in brackets after the SP values in the text.

Table 1. Concentration $\left(\mathrm{mg} \cdot \mathrm{L}^{-1}\right)$ of sodium percarbonate added in the containers and concentration of hydrogen peroxide released in the water by its breakdown.

\begin{tabular}{|c|c|c|}
\hline Treatment & $\begin{array}{l}\text { Sodium Percarbonate (SP) } \\
\qquad\left(2 \mathrm{Na}_{2} \mathrm{CO}_{3} \cdot 3 \mathrm{H}_{2} \mathrm{O}_{2}\right)\end{array}$ & $\begin{array}{l}\text { Hydrogen Peroxide (HP) } \\
\qquad\left(\mathrm{H}_{2} \mathrm{O}_{2}\right)\end{array}$ \\
\hline Control & $0.0 \mathrm{mg} \cdot \mathrm{L}^{-1}$ & $0.0 \mathrm{mg} \cdot \mathrm{L}^{-1}$ \\
\hline $\mathrm{T} 1$ & $5.0 \mathrm{mg} \cdot \mathrm{L}^{-1}$ & $1.4 \mathrm{mg} \cdot \mathrm{L}^{-1}$ \\
\hline $\mathrm{T} 2$ & $10.0 \mathrm{mg} \cdot \mathrm{L}^{-1}$ & $2.8 \mathrm{mg} \cdot \mathrm{L}^{-1}$ \\
\hline T3 & $20.0 \mathrm{mg} \cdot \mathrm{L}^{-1}$ & $5.5 \mathrm{mg} \cdot \mathrm{L}^{-1}$ \\
\hline $\mathrm{T} 4$ & $30.0 \mathrm{mg} \cdot \mathrm{L}^{-1}$ & $8.3 \mathrm{mg} \cdot \mathrm{L}^{-1}$ \\
\hline $\mathrm{T} 5$ & $40.0 \mathrm{mg} \cdot \mathrm{L}^{-1}$ & $11.1 \mathrm{mg} \cdot \mathrm{L}^{-1}$ \\
\hline T6 & $50.0 \mathrm{mg} \cdot \mathrm{L}^{-1}$ & $13.8 \mathrm{mg} \cdot \mathrm{L}^{-1}$ \\
\hline $\mathrm{T} 7$ & $60.0 \mathrm{mg} \cdot \mathrm{L}^{-1}$ & $16.6 \mathrm{mg} \cdot \mathrm{L}^{-1}$ \\
\hline
\end{tabular}

To test the immediate acute effect on Daphnia of SP addition to the aquatic environment, the experiment was left to run for $24 \mathrm{~h}$ at room temperature (approximately $20^{\circ} \mathrm{C}$ ) under natural light conditions, and without an additional supply of oxygen. This was to ensure a close approximation to the natural conditions of the sampling location in terms of: temperature (see above), light (a natural daily cycle) and oxygen availability (phytoplankton would have still provided an oxygen source in proportion to their response to SP concentrations). Moreover, the considerably large surface to volume ratio of the sample containers would allow diffusion to cover some of the additional oxygen demand in a manner similar to surface waters.

At the end of the experiment all zooplankton individuals were separated into living and dead fractions for each treatment, then preserved with formaldehyde (4\%) in separate sample tubes. Zooplankton was identified using a binocular stereoscopic microscope with the aid of diagrams and keys modified from Chapman [31]. Copepoda were identified to the level of order with three orders being represented: (1) Calanoida, (2) Cyclopoida and (3) Harpacticoida. Cladocera were identified to genus or family level. All animals were measured along their major axes; for Daphnia, the length of the major axis from the upper eye to the tip of the tail spine was recorded. The size categories were $0.2 \mathrm{~mm}, 0.5 \mathrm{~mm}, 0.7 \mathrm{~mm}, 1.0 \mathrm{~mm}, 1.2 \mathrm{~mm}, 1.5 \mathrm{~mm}$ and $2.0 \mathrm{~mm}$.

All statistical analyses were conducted using the statistics packages IBM SPSS statistics $23^{\circledR}$ (IBM Corporation, New York, NY, USA) and GraphPad Prism (GraphPad Software, San Diego, CA, USA) and Microsoft Excel ${ }^{\circledR}$ (Microsoft Corporation, Redmond, WA, USA). A 95\% confidence level $(p \leq 0.05)$ was chosen for all tests unless otherwise stated. To establish the strength of the relationship with SP concentration and zooplankton survival, a step-by-step approach was taken. Firstly, data on the percentage of individuals alive after $24 \mathrm{~h}$ were correlated with concentration using Spearman's rank to confirm variable association. In the second stage of analysis, linear, quadratic, cubic and four parameter logistic (4PL) regression were applied following McDonald [32]. The percentage survival data were obtained by transforming the raw binominal data (i.e., 'dead' or 'alive') into ratio variables (i.e., percentage values). Finally, binominal logistic regression was performed to obtain information on the probability of survival of Daphnia and to assess differences between the different sizes. 


\section{Results}

A total of 1944 individuals belonging to seven different systematic groups were counted: four from the order of Cladocera, namely Daphnia (1610), Bosminidae (2), Chydoridae (1) and Scapholeberis (2), and three from subclass Copepoda, namely Calanoida (272), Cyclopoida (44) and Harpacticoida (14). Daphnia were the most numerous zooplankton group by far; therefore, it was decided that further detailed analyses were only to be performed on this genus (Table 2), though the actual number of animals from all identified groups are provided in the Table S1 in the Supplementary Materials.

Table 2. Total number of individuals per mesocosm. Concentration of sodium percarbonate (SP) $\left(\mathrm{mg} \cdot \mathrm{L}^{-1}\right)$. Standard deviation for the control (SD).

\begin{tabular}{ccccccccc}
\hline Species & Control (Mean) & T1: 5 SP & T2: 10 SP & T3: 20 SP & T4: 30 SP & T5: 40 SP & T6: 50 SP & T7: 60 SP \\
\hline Daphnia sp. & $\begin{array}{r}79.6 \\
\text { SD } 47\end{array}$ & 280 & 292 & 150 & 185 & 104 & 95 & 265 \\
\hline
\end{tabular}

\section{Total Mortality and Concentration of SP}

In the control, $97.9 \%$ of Daphnia were alive after $24 \mathrm{~h}$. At a concentration of $5.0 \mathrm{mg} \cdot \mathrm{L}^{-1} \mathrm{SP}$ $\left(1.4 \mathrm{mg} \cdot \mathrm{L}^{-1} \mathrm{HP}\right)$ the percentage of living individuals decreased slightly. The next treatment, $10.0 \mathrm{mg} \cdot \mathrm{L}^{-1}$ SP (2.8 $\left.\mathrm{mg} \cdot \mathrm{L}^{-1} \mathrm{HP}\right)$, showed a further small decrease. This was followed by a more pronounced decrease at $20.0 \mathrm{mg} \cdot \mathrm{L}^{-1} \mathrm{SP}\left(5.5 \mathrm{mg} \cdot \mathrm{L}^{-1} \mathrm{HP}\right)$. Between $20.0 \mathrm{mg} \cdot \mathrm{L}^{-1} \mathrm{SP}\left(5.5 \mathrm{mg} \cdot \mathrm{L}^{-1} \mathrm{HP}\right)$ and $30.0 \mathrm{mg} \cdot \mathrm{L}^{-1}$ $\mathrm{SP}\left(8.3 \mathrm{mg} \cdot \mathrm{L}^{-1} \mathrm{HP}\right)$ a dramatic decrease of almost 50 percentage points was observed. At $40.0 \mathrm{mg} \cdot \mathrm{L}^{-1} \mathrm{SP}$ $\left(11.1 \mathrm{mg} \cdot \mathrm{L}^{-1} \mathrm{HP}\right)$ the percentage of living Daphnia dropped to $3 \%$, while at $50.0 \mathrm{mg} \cdot \mathrm{L}^{-1} \mathrm{SP}\left(13.8 \mathrm{mg} \cdot \mathrm{L}^{-1}\right.$ $\mathrm{HP}$ ), only $1.1 \%$ of Daphnia were still alive. The final treatment, $60.0 \mathrm{mg} \cdot \mathrm{L}^{-1} \mathrm{SP}\left(16.6 \mathrm{mg} \cdot \mathrm{L}^{-1} \mathrm{HP}\right)$, saw all individuals expire (Table 3). For zooplankton other than Daphnia a general downward trend was also observed. However, the small sample size and a number of outliers, particularly in the control and $50.0 \mathrm{mg} \cdot \mathrm{L}^{-1} \mathrm{SP}\left(13.8 \mathrm{mg} \cdot \mathrm{L}^{-1} \mathrm{HP}\right)$ treatments, prevented further analysis.

Table 3. Concentration of SP $\left(\mathrm{mg} \cdot \mathrm{L}^{-1}\right)$, Daphnia survival percentage and actual numbers of living and dead individuals. Standard deviation for percentage of living Daphnia in the control (SD).

\begin{tabular}{ccccccccc}
\hline \multirow{2}{*}{ Species } & Control (Mean) & $\begin{array}{c}\text { T 1: } \\
\mathbf{5} \text { SP }\end{array}$ & $\begin{array}{c}\text { T2: } \\
\text { 10 SP }\end{array}$ & $\begin{array}{c}\text { T3: } \\
\text { 20 SP }\end{array}$ & $\begin{array}{c}\text { T4: } \\
\text { 30 SP }\end{array}$ & $\begin{array}{c}\text { T5: } \\
\text { 40 SP }\end{array}$ & $\begin{array}{c}\text { T6: } \\
\text { 50 SP }\end{array}$ & $\begin{array}{c}\text { T7: } \\
\mathbf{6 0} \text { SP }\end{array}$ \\
\hline \multirow{2}{*}{ Percentage living Daphnia } & $\begin{array}{c}97.9 \\
\text { SD 1.23 }\end{array}$ & 93.9 & 91.1 & 66.0 & 16.8 & 2.9 & 1.1 & 0.0 \\
\hline Living & 77 & 263 & 266 & 99 & 31 & 3 & 1 & 0 \\
\hline Dead & 2.6 & 17 & 26 & 51 & 154 & 101 & 95 & 265 \\
\hline
\end{tabular}

Using Spearman's rank correlation, a strong inverse relationship was found to exist between SP concentration and percentage of living Daphnia $(\mathrm{r}=-0.976, p<0.0005, \mathrm{~N}=8)$. Linear regression was significant $\left(\mathrm{R}^{2}=0.901, p<0.0003, \mathrm{~F}=54.826\right)$, and quadratic and cubic regression had a lower level of significance (both $p=0.001$ ) and $\mathrm{R}^{2}$ values of 0.942 and $0.978(\mathrm{~F}=40.909$ and $\mathrm{F}=58.970$, respectively). Four parameter logistic regression showed the highest $\mathrm{R}^{2}$ value $(0.998)$ with $p=0.0004$ and $\mathrm{F}=97.15$ in comparison to first order polynomial (straight line) linear regression (Figure 1).

For these data the dependent variable can be expressed as a percentage, or in two categories, i.e., whether or not an individual survived the experiment. Binominal logistic regression was used to estimate the probability of an event occurring (death of an organism following $24 \mathrm{~h}$ of exposure) based on the independent variables provided (concentration of SP $\left(\mathrm{mg} \cdot \mathrm{L}^{-1}\right)$ ).

Grouping all of the differently sized individuals together, the results indicate that the concentration of SP was a significant predictor of mortality (Chi-Square $=1429.918, \mathrm{df}=1$ and $p=0.001$ ). Sodium percarbonate concentration explains $91.3 \%$ of the variability of animal deaths, 35.9\% greater than the preliminary Block 0 model which only bases the prediction on which category has a higher frequency (55.4\% of variability was explained by this model). Concentration was a significant factor at the 
0.001 level $($ Wald $=407.442, p<0.0005$, Odds Ratio $(\mathrm{OR})=0.839)$. The Hosmer-Lemeshow test produced the desired non-significant value $(p=0.117)$ indicating that there was not a significant difference between the observed value and the values predicted by this model. In Figure $2 \mathrm{a}$ the probability for each individual either surviving or dying during the 24-h experiment is displayed, with individuals scoring above 0.5 having a probability towards surviving and those below 0.5 towards dying.

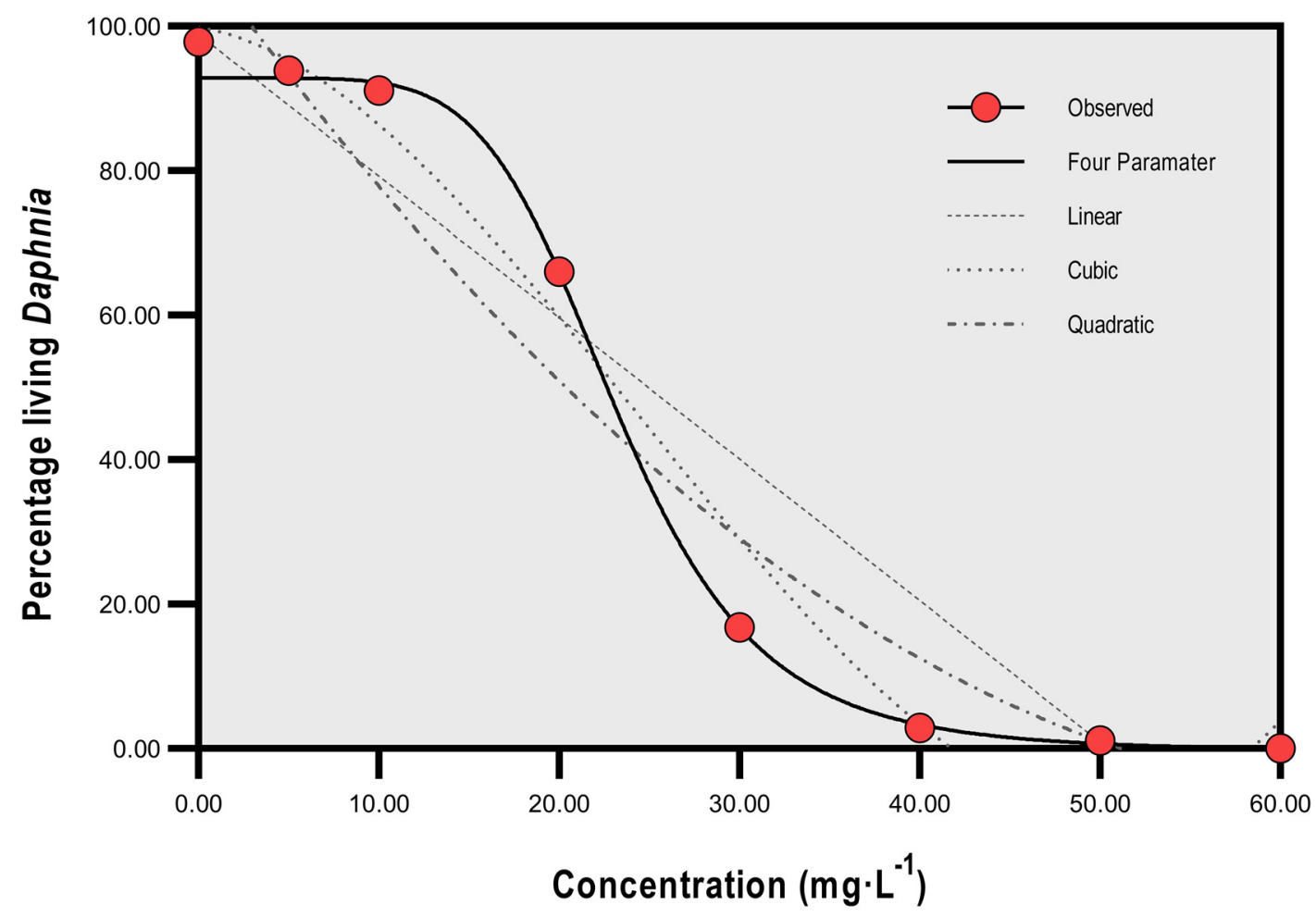

Figure 1. Regression lines for percentage survival of Daphnia and concentration of sodium percarbonate $\left(\mathrm{mg} \cdot \mathrm{L}^{-1}\right)$.

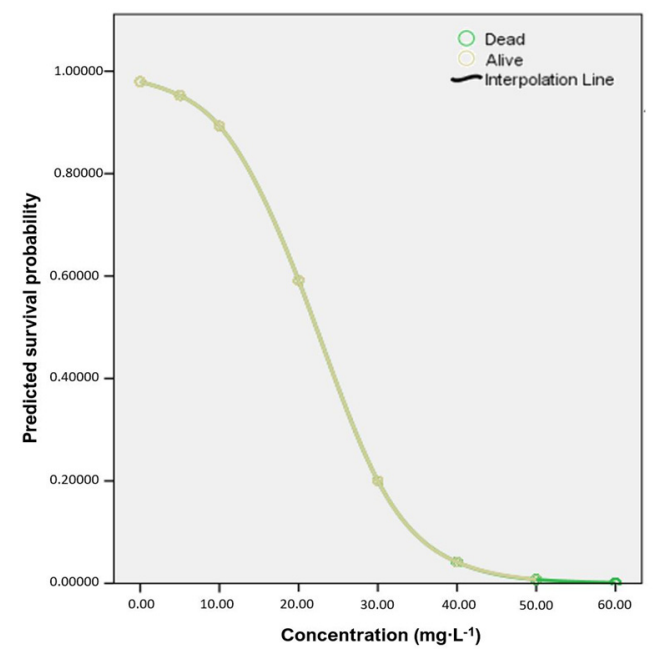

(a)

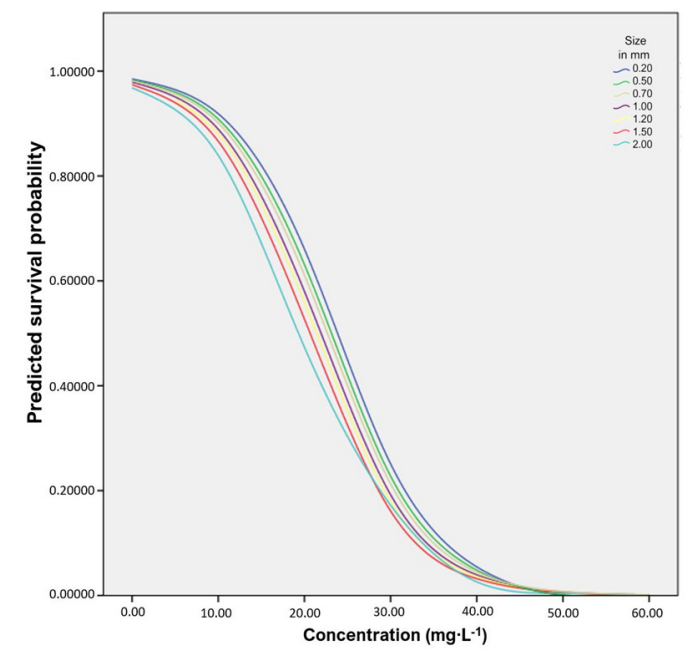

(b)

Figure 2. Predicted probability of survival dependent on sodium percarbonate concentration: (a) Grouped size; the line shows only values for dead individuals after $50 \mathrm{mg} \cdot \mathrm{L}^{-1}$ (darker green) because there were no surviving individuals beyond that concentration; the prediction was based only on dead individuals. (b) The relationship between predicted probability of survival of different Daphnia size classes and sodium percarbonate concentration. 
The analysis between size, concentration and mortality can be observed in Figure $2 b$, which presents the survival probability of each size category when included as a covariate scale variable alongside concentration. The justification for this is that size categories in themselves are artificial, since length is, in nature, a ratio variable (denoted as a 'scale variable' in the SPSS package (IBM Corporation, New York, NY, USA)).

In this case the accuracy of the prediction increased by $36.4 \%$ from $54.8 \%$ (Block 0 ) to 91.0\%. Concentration was significant below the 0.0005 level (Wald $=390.942 p \leq 0.0005$, Odds Ratio $(\mathrm{OR})=0.839)$, whereas size was not significant $(p=0.111$, Wald $=2.541$, Odds Ratio $(\mathrm{OR})=0.651)$. The pseudo $\mathrm{R}^{2}$ value suggests that this model explains between $58.9 \%$ and $78.8 \%$ of the variance seen $(p=0.0005$, Cox \& Snell R Square $=0.589$, Nagelkerke R Square $=0.788)$. The Hosmer-Lemeshow test showed a significant difference $(p=0.001)$ between the observed values and the values predicted by this model. All size classes showed a tipping point at around $10 \mathrm{mg} \cdot \mathrm{L}^{-1}$, when the probability of survival began to rapidly fall. Additionally, larger individual Daphnia appeared to show higher sensitivity to SP than smaller individuals, indicated by the largest Daphnia on the far left side of the curves and smaller individuals progressively shifting towards the right, with the smallest individual Daphnia in the furthest curve to the right.

\section{Discussion}

The experimental design applied in this study allowed changes in experimental treatments to be attributed to the increasing concentration of SP, because the three control replicates with $97.9 \% \pm 1.23$ of living Daphnia showed that enclosure effect was negligible. Furthermore, the gradient of SP concentrations allowed the non-linear response of Daphnia to be traced. According to Kreyling et al. [33], experiments with a gradient of factors outperform replication-based experiments in capturing non-linear responses to various environmental drivers. Accordingly, analysis of the results of our experiment showed that increasing concentrations of SP causes mortality to rise gradually but non-linearly. Additionally, both measured results and binominal regression showed a steep drop in survival in treatments containing between $10.0 \mathrm{mg} \cdot \mathrm{L}^{-1} \mathrm{SP}\left(2.8 \mathrm{mg} \cdot \mathrm{L}^{-1} \mathrm{HP}\right)$ and $20.0 \mathrm{mg} \cdot \mathrm{L}^{-1} \mathrm{SP}\left(5.5 \mathrm{mg} \cdot \mathrm{L}^{-1} \mathrm{HP}\right)$, with the $\mathrm{LC}_{50}$ value falling within the range between 20.0 and $30.0 \mathrm{mg} \cdot \mathrm{L}^{-1} \mathrm{SP}\left(8.3 \mathrm{mg} \cdot \mathrm{L}^{-1} \mathrm{HP}\right)$.

The single, acute dosage had a very low threshold (the smallest amount of SP that caused a measurable effect). Although it is difficult to obtain the exact threshold dose based on our data, slight negative effects were observed at the lowest applied SP concentrations of $5.0 \mathrm{mg} \cdot \mathrm{L}^{-1} \mathrm{SP}\left(1.4 \mathrm{mg} \cdot \mathrm{L}^{-1}\right.$ HP; $93.9 \%$ living Daphnia as compared to $97.9 \%$ in the control samples). Meinertz et al. [34] found that chronic concentrations below $1.25 \mathrm{mg} \cdot \mathrm{L}^{-1} \mathrm{HP}$ did not significantly affect $D$. magna, while Reichwaldt et al. [35] showed that the $\mathrm{LC}_{50}$ for Daphnia sp. was $5.6 \mathrm{mg} \cdot \mathrm{L}^{-1} \mathrm{HP}$ with no observed adverse effects at concentrations as high as $3.0 \mathrm{mg} \cdot \mathrm{L}^{-1} \mathrm{HP}$. Similarly, in this study more than ninety percent of Daphnia remained alive after exposure to both $5.0 \mathrm{mg} \cdot \mathrm{L}^{-1} \mathrm{SP}\left(1.4 \mathrm{mg} \cdot \mathrm{L}^{-1} \mathrm{HP}\right)$ and $10.0 \mathrm{mg} \cdot \mathrm{L}^{-1} \mathrm{SP}\left(2.8 \mathrm{mg} \cdot \mathrm{L}^{-1}\right.$ $\mathrm{HP}$ ) after $24 \mathrm{~h}$, but at higher measured concentrations survival declined rapidly.

At much higher concentrations over a longer period, Wasielak [36] tested Envolab's SP formulation using the same artificial lake water sample at concentrations between $60.0 \mathrm{mg} \cdot \mathrm{L}^{-1} \mathrm{SP}\left(16.6 \mathrm{mg} \cdot \mathrm{L}^{-1}\right.$ $\mathrm{HP})$ to $300 \mathrm{mg} \cdot \mathrm{L}^{-1} \mathrm{SP}\left(83.0 \mathrm{mg} \cdot \mathrm{L}^{-1} \mathrm{HP}\right)$. Following the addition of $60.0 \mathrm{mg} \cdot \mathrm{L}^{-1} \mathrm{SP}\left(16.6 \mathrm{mg} \cdot \mathrm{L}^{-1} \mathrm{HP}\right)$ crustacean zooplankton recovered to around $75 \%$ of their original abundance after 10 days, from a low point of around $50 \%$ at 5 days after addition. Zooplankton in the $180 \mathrm{mg} \cdot \mathrm{L}^{-1} \mathrm{SP}\left(49.8 \mathrm{mg} \cdot \mathrm{L}^{-1} \mathrm{HP}\right)$ and $300 \mathrm{mg} \cdot \mathrm{L}^{-1} \mathrm{SP}\left(83.0 \mathrm{mg} \cdot \mathrm{L}^{-1} \mathrm{HP}\right)$ treatments did not recover to more than $20 \%$ of their initial abundance within 10 days.

With regards to the sodium and carbonate components of sodium percarbonate and their effects on $\mathrm{pH}$ and alkalinity, $\mathrm{pH}$ values greater than 9.7 were not observed in mesocosm experiments following the addition of up to $300.0 \mathrm{mg} \cdot \mathrm{L}^{-1} \mathrm{SP}\left(83.0 \mathrm{mg} \cdot \mathrm{L}^{-1} \mathrm{HP}\right)$ [36], while with $60 \mathrm{mg} \cdot \mathrm{L}^{-1} \mathrm{SP}$ (the maximal concentration used in our experiment) the $\mathrm{pH}$ of 8.4 was well within natural daily fluctuations in eutrophic lake water. Furthermore, with a buffering capacity of $106 \mathrm{mg} \cdot \mathrm{L}^{-1} \mathrm{HCO}_{3}{ }^{-}$(the mean value of 77 European rivers), the addition of $102 \mathrm{mg} \cdot \mathrm{L}^{-1}$ of sodium carbonate would be needed to raise $\mathrm{pH}$ from 
8.3 to 10.0 [37]. Regarding alkalinity, Bogart et al. [38] exposed D. magna to a combination of extreme shifts in hardness and alkalinity. Only extremely high $\left(420 \mathrm{mg} \cdot \mathrm{L}^{-1} \mathrm{CaCO}_{3}\right.$ alkalinity and $600 \mathrm{mg} \cdot \mathrm{L}^{-1}$ $\mathrm{CaCO}_{3}$ water hardness) increases caused significant mortality after $72-96 \mathrm{~h}$ of exposure, albeit with calcium carbonate and not sodium carbonate. Warne \& Schifko [39] analyzed the toxicity of numerous laundry detergent components, finding that sodium carbonate had a $48-\mathrm{h} \mathrm{EC} 50$ of $199.82 \mathrm{mg} \cdot \mathrm{L}^{-1}$ for the Cladocera Ceriodaphnia dubia. Given these results and the findings from Beklioglu and Moss [26], we suggest that the effects of changes in $\mathrm{pH}$ and alkalinity on Daphnia in our mesocosms would not be a significant contributor to mortality seen.

ROS can cause oxidative stress with the layers of cells becoming detached from tissues because of the formation of gas embolies [19]. Toxicity is likely to be because of ROS molecules reaching active sites within organisms [40]. Larger organisms must be exposed to higher concentrations to experience the same exposure per unit mass. Because of this it was initially thought that larger individual Daphnia would have benefited from a smaller surface area to volume ratio (SA:V) leading to less cell damage per unit of biomass. However, size differences were not shown to be statistically significant $(p=0.111)$ and based upon the pattern seen in Figure $2 b$ there are some indications that large Daphnia may have experienced higher levels of mortality during the experiment. This non-significant finding may be explained by the fact that zooplankton are generally small enough to not require specialized respiratory surfaces and may acquire enough oxygen through integumental respiration [41,42]. The circulatory system of Daphnia also appears to lack specific sites for respiratory gas exchange and tissue transfer [43]. Therefore, the range of sizes of the Daphnia measured in this experiment $(0.2-2.0 \mathrm{~mm})$ may not have been wide enough for differences in mortality to be significant within $24 \mathrm{~h}$ at the measured levels of exposure to SP. Daphnia creates a dual-purpose feeding current that flows from the anterior to the posterior by beating its legs [41,44]. Pirow et al. [45] found that the partial pressure of oxygen in the water leaving the feeding chamber was significantly lower than that in water entering the chamber, indicating that oxygen was extracted between the inner and outer walls of the carapace. Burns [46] and Egloff and Palmer [47] found that the volume of filtered water and filtering rate increases with length of the body. Larger Daphnia may have filtered a greater proportion of water containing ROS than smaller individuals and may have increased their exposure to oxidative stress in this way. If larger Daphnia filter a proportionally greater volume of water, the transfer of ROS across the thin wall of the inner carapace was probably more effective in increasing exposure to ROS, which may have caused the higher levels of predicted mortality.

Additionally, Daphnia-sized aquatic animals have a layer of surrounding water which depends on the relative velocity of movement of their surroundings [41]. Pirow et al. [45] found a positive correlation between appendage beat rates and the flow rate of the medium around the animals, and Pirow and Buchen [43] suggest that oxygen supply may also be enhanced by ventilatory flow reducing fluid boundary layers, leading to greater levels of oxygen diffusion. Increased relative filtration rates would have served to reduce the fluid boundary layer between the epidermal layer and the ROS in the water, also resulting in a higher level of exposure for larger individuals. All of this may explain why it was not the case that smaller Daphnia were actually more affected by SP, with the opposite being suggested by these preliminary results. However, it must be kept in mind that because Daphnia were not identified to the species level, any differentiation in ROS tolerance between individuals that were not members of the same species would not have been accounted for in the analysis. To this point, Reichwaldt et al. [35] suggest that the differences observed in survival following HP exposure between Moina and Daphnia species were because of their different abilities to withstand oxidative stress, caused by higher levels of enzymes such as catalase, peroxidase and superoxide dismutase.

Geer et al. [40] assessed the effects of the HP-generating algaecide Phycomycins ${ }^{\circledR}$ SCP on various animals including Ceriodaphnia dubia, a member of the Daphniidae family, the cyanobacterium Microcystis aeruginosa and the chlorophyte Pseudokirchneriella subcapitata. They found that $\mathrm{EC}_{50}$ values, based on cell density and chlorophyll $a$ concentration for phytoplankton, were 0.9 to $1.0 \mathrm{mg} \cdot \mathrm{L}^{-1} \mathrm{HP}$ 
(over $96 \mathrm{~h}$ ) for the cyanobacterium and 5.2 to $9.2 \mathrm{mg} \cdot \mathrm{L}^{-1} \mathrm{HP}$ for the chlorophyte (over 7 days). The $\mathrm{LC}_{50}$ value over $96 \mathrm{~h}$ for the $C$. dubia was $1.0 \mathrm{mg} \cdot \mathrm{L}^{-1} \mathrm{HP}$. Of the animals studied, $C$. dubia showed the highest sensitivity to HP equivalent concentrations with the authors suggesting that this was a result of the smaller size in comparison to other organisms under study (see above). Because the size structure of the Daphnia community was not uniform in all containers, the indication of higher vulnerability of larger Daphnia to ROS should be considered as preliminary results. Given the importance for lake management, further studies taking the effect of SP on Daphnia eggs and various sizes into consideration will be conducted to gain a more comprehensive understanding of the potential effects of SP on other stages of the lifecycle of Daphnia.

Crafton et al. [48] investigated the effects of the SP formulation PAK ${ }^{\circledR} 27$, finding that $6.2 \mathrm{mg} \cdot \mathrm{L}^{-1} \mathrm{HP}$ equivalent led to statistically significant reductions in cyanobacterial populations and increases in the abundance of other classes of phytoplankton. Furthermore, results obtained by Kędzierska [49] showed that $20.0 \mathrm{mg} \cdot \mathrm{L}^{-1} \mathrm{SP}\left(5.5 \mathrm{mg} \cdot \mathrm{L}^{-1} \mathrm{HP}\right)$ of the SP formulation CYANOXIDE ${ }^{\circledR}$ reduced cyanobacteria from $63 \%$ of the phytoplankton assemblage to less than $5 \% 6$ days after application in a $300 \mathrm{~L}$ experimental tank. Cyanobacteria did not recover over the 25-day duration of the experiment, while other phytoplankton groups increased in abundance. However, Sinha et al. [16] found that while $2.5 \mathrm{mg} \cdot \mathrm{L}^{-1} \mathrm{HP}$ did not negatively affect non-target algal and zooplankton communities, negative effects were observed in their $4.0 \mathrm{mg} \cdot \mathrm{L}^{-1} \mathrm{HP}$ treatment in comparison to the control and the $2.5 \mathrm{mg} \cdot \mathrm{L}^{-1}$ HP treatment.

We find the above particularly significant because at concentrations greater than $10.0 \mathrm{mg} \cdot \mathrm{L}^{-1}$ SP $\left(2.8 \mathrm{mg} \cdot \mathrm{L}^{-1} \mathrm{HP}\right)$, we also began to see a rapid decline in Daphnia suggesting that concentrations below $10.0 \mathrm{mg} \cdot \mathrm{L}^{-1} \mathrm{SP}\left(2.8 \mathrm{mg} \cdot \mathrm{L}^{-1} \mathrm{HP}\right)$ may be able to reduce cyanobacterial abundance, while having a reduced impact on non-target zooplankton and phytoplankton. Moreover, numerous studies using direct HP application have shown that concentrations below $2.8 \mathrm{mg} \cdot \mathrm{L}^{-1} \mathrm{HP}$ have significant effects on cyanobacterial abundance in experimental laboratory conditions and in whole lake experiments $[9,12,15]$. As noted by Sinha et al. [16] and in line with our original concerns regarding the effects of top-down control, concentrations greater than $10.0 \mathrm{mg} \cdot \mathrm{L}^{-1} \mathrm{SP}\left(2.8 \mathrm{mg} \cdot \mathrm{L}^{-1} \mathrm{HP}\right)$ may also impact non-cyanobacterial phytoplankton, thereby reducing potential food sources for Daphnia and other zooplankton.

\section{Conclusions}

In conjunction with these cited works, our findings show that ROS released following the degradation of SP have a non-linear effect on the mortality of zooplankton over a very short period, with an apparent tipping point followed by a steep drop in survival in treatments containing $10.0 \mathrm{mg} \cdot \mathrm{L}^{-1}\left(2.8 \mathrm{mg} \cdot \mathrm{L}^{-1} \mathrm{HP}\right)$ or more of SP. For individual Daphnia ranging in size from 0.2 to $2.0 \mathrm{~mm}$ no significant difference in survival was observed, with the suggestion that large individuals may be more vulnerable to the SP than the smaller individuals, which was in contradiction to our initial speculations, as explained above.

Given the importance of Daphnia as a keystone species in exercising control over the biomass and structure of phytoplankton in lakes and many other water bodies through top-down control, we suggest that the amount of SP that should be added to a lake to combat cyanobacterial occurrence while limiting collateral damage to zooplankton should be below $10.0 \mathrm{mg} \cdot \mathrm{L}^{-1} \mathrm{SP}\left(2.8 \mathrm{mg} \cdot \mathrm{L}^{-1} \mathrm{HP}\right)$ and possibly less than $5.0 \mathrm{mg} \cdot \mathrm{L}^{-1} \mathrm{SP}\left(1.4 \mathrm{mg} \cdot \mathrm{L}^{-1} \mathrm{HP}\right)$.

Supplementary Materials: The following are available online at http://www.mdpi.com/2073-4441/12/5/1304/s1, Table S1: Number of individuals representing various taxonomic groups per microcosm in three controls and seven experimental treatments, Figure S1: The changes of $\mathrm{pH}$ at various concentrations of Envolab's sodium percarbonate.

Author Contributions: Conceptualization, I.J., W.S.; formal analysis, R.T., methodology, I.J.; R.T., investigation, R.T.; visualization, R.T.; writing一original draft preparation, R.T.; writing-review and editing, R.T.; I.J.; W.S., supervision, I.J. All authors have read and agreed to the published version of the manuscript.

Funding: This work was supported by the statutory program of the Department of Microbial Ecology and Environmental Biotechnology, Faculty of Biology, University of Warsaw. 
Acknowledgments: The authors thank colleagues from the Department of Microbial Ecology and Environmental Biotechnology and from the Environmental Management Master's Program at the Biology Faculty UW for support during the experimental works.

Conflicts of Interest: The authors declare no conflict of interest.

\section{References}

1. Shurin, J.B.; Gruner, D.S.; Hillebrand, H. All wet or dried up? Real differences between aquatic and terrestrial food webs. Proc. R. Soc. B Biol. Sci. 2005, 273, 1-9. [CrossRef] [PubMed]

2. Field, C.B.; Behrenfeld, M.J.; Randerson, J.T.; Falkowski, P. Primary production of the biosphere: Integrating terrestrial and oceanic components. Science 1998, 281, 237-240. [CrossRef] [PubMed]

3. Anderson, D.M. Prevention, control, and mitigation of harmful algal blooms: Multiple approaches to HAB management. In Harmful Algae Management mitigate, Heng Mui Keng, Terrace, Singapore, 21 December 2004; Etheridge, S., Anderson, D., Kleindinst, J., Zhu, M., Zou, Y., Eds.; Asia Pacific Economic Cooperation: Heng Mui Keng Terrace, Singapore, 2004; pp. 123-130.

4. Barrington, D.; Xiao, X.; Coggins, L.; Ghadouani, A. Control and management of harmful algal blooms. In Climate Change and Marine and Freshwater Toxins Botana; Louzao, L.M., Vilariño, M.C., Eds.; N. De Gruyter: Berlin, Germany, 2015; pp. 313-358. ISBN 978-3-11-033303-9.

5. Meriluoto, J.; Blaha, L.; Bojadzija, G.; Bormans, M.; Brient, L.; Codd, G.A.; Drobac, D.; Faassen, E.J.; Fastner, J.; Hiskia, A.; et al. Toxic cyanobacteria and cyanotoxins in european waters-Recent Progress Achieved through the CYANOCOST Action and Challenges for Further Research. Adv. Oceanogr. Limnol 2017, 8, 161-178. [CrossRef]

6. Medrano, E.A.; Uittenbogaard, R.; Wiel, B.V.D.; Pires, L.D.; Clercx, H. An alternative explanation for cyanobacterial scum formation and persistence by oxygenic photosynthesis. Harmful Algae 2016, 60, 27-35. [CrossRef]

7. Tiling, K.; Proffitt, C.E. Effects of Lyngbya Majuscula blooms on the seagrass Halodule Wrightii and resident invertebrates. Harmful Algae 2017, 62, 104-112. [CrossRef]

8. Ghadouani, A.; Pinel-Alloul, B.; Prepas, E.E. Effects of experimentally induced cyanobacterial blooms on crustacean zooplankton communities. Freshw. Biol. 2003, 48, 363-381. [CrossRef]

9. Weenink, E.F.J.; Luimstra, V.M.; Schuurmans, J.M.; Herk, M.J.V.; Visser, P.M.; Matthijs, H.C.P. Combatting Cyanobacteria with Hydrogen Peroxide: A laboratory study on the consequences for phytoplankton community and diversity. Front. Microbiol. 2015, 6. [CrossRef]

10. Dokulil, M.T.; Teubner, K. Cyanobacterial dominance in lakes. Hydrobiologia 2000, 438, 1-12. [CrossRef]

11. Matthijs, H.C.P.; Jančula, D.; Visser, P.M.; Maršálek, B. Existing and emerging cyanocidal compounds: New perspectives for cyanobacterial bloom mitigation. Aquat. Ecol. 2016, 50, 443-460. [CrossRef]

12. Drábková, M.; Admiraal, W.; Maršálek, B. Combined exposure to hydrogen peroxide and light selective effects on cyanobacteria, green algae, and diatoms. Environ. Sci. Technol. 2007, 41, 309-314. [CrossRef]

13. Apel, K.; Hirt, H. Reactive oxygen species: Metabolism, oxidative stress, and signal transduction. Annu. Rev. Plant Biol. 2004, 55, 373-399. [CrossRef] [PubMed]

14. Veljovic-Jovanovic, S. Active oxygen species and photosynthesis: Mehler and ascorbate peroxidase reactions. Iugoslav Physiol. Pharmacol. Acta 1998, 34, 503-522.

15. Matthijs, H.C.; Visser, P.M.; Reeze, B.; Meeuse, J.; Slot, P.C.; Wijn, G.; Talens, R.; Huisman, J. Selective suppression of harmful cyanobacteria in an entire lake with hydrogen peroxide. Water Res. 2012, 46, 1460-1472. [CrossRef] [PubMed]

16. Sinha, A.K.; Eggleton, M.A.; Lochmann, R.T. An environmentally friendly approach for mitigating cyanobacterial bloom and their toxins in hypereutrophic ponds: Potentiality of a newly developed granular hydrogen peroxide-based compound. Sci. Total Environ. 2018, 637-638, 524-537. [CrossRef]

17. Massachusetts Department of Environmental Protection-Hydrogen Peroxide, Peracetic Acid and Sodium Percarbonate. Available online: http://www.mass.gov/eea/docs/agr/pesticides/aquatic/sodium-carbonateperoxyhydrate-and-hydrogen-peroxide.pdf (accessed on 10 October 2016).

18. Wilson, A.E.; Sarnelle, O.; Tillmanns, A.R. Effects of cyanobacterial toxicity and morphology on the population growth of freshwater zooplankton: Meta-analyses of laboratory experiments. Limnol. Oceanogr. 2006, 51, 1915-1924. [CrossRef] 
19. Lampert, W. Laboratory studies on zooplankton-cyanobacteria interactions. N. Z. J. Mar. Freshw. Res. 1987, 21, 483-490. [CrossRef]

20. Lampert, W. Zooplankton research: The contribution of limnology to general ecological paradigms. Aquat. Ecol. 1997, 31, 19-27. [CrossRef]

21. Sarnelle, O. Daphnia as keystone predators: Effects on phytoplankton diversity and grazing sesistance. J. Plankton Res. 2005, 27, 1229-1238. [CrossRef]

22. Wogram, J.; Liess, M. Rank ordering of macroinvertebrate species sensitivity to toxic compounds by comparison with that of Daphnia Magna. Bull. Environ. Contam. Toxicol. 2001, 67, 360-367.

23. Wetzel, R. Limnology, 3rd ed.; Academic Press: Cambridge, MA, USA, 2001; p. 1006.

24. Pedersen, F.; Hansen, P. Effects of high $\mathrm{pH}$ on the growth and survival of six marine heterotrophic protists. Mar. Ecol. Prog. Ser. 2003, 260, 33-41. [CrossRef]

25. Yin, X.W.; Niu, C.J. Effect of pH on Survival, Reproduction, Egg Viability and Growth Rate of Five Closely Related Rotifer Species. Aquat. Ecol. 2007, 42, 607-616. [CrossRef]

26. Beklioglu, M.; Moss, B. The Impact of $\mathrm{pH}$ on interactions among phytoplankton algae, zooplankton and perch (Perca Fluviatilis) in a Shallow, Fertile Lake. Freshw. Biol. 1995, 33, 497-509. [CrossRef]

27. Reynolds, C. The Ecology of Phytoplankton; Cambridge University Press: Cambridge, UK; Melbourne, Australia; Madrid, Spain; Cape Town, South Africa; Singapore; São Paulo, Brazil, 2006; p. 551.

28. McQueen, D.J.; Post, J.R.; Mills, E.L. Trophic relationships in freshwater pelagic ecosystems. Can. J. Fish. Aquat. Sci. 1986, 43, 1571-1581. [CrossRef]

29. Christoffersen, K.; Riemann, B.; Klysner, A.; Søndergaard, M. Potential role of fish predation and natural populations of zooplankton in structuring a plankton community in eutrophic lake water. Limnol. Oceanogr. 1993, 38, 561-573. [CrossRef]

30. Envolab Fine Chemicals Nadwęglan sodu. Available online: https://envolab.pl/sklep/nadweglan-sodu-12kg/ (accessed on 1 January 2016).

31. Chapman, M.A.; Lewis, M.H.; Stout, V.M. Introduction to the freshwater crustacea of New Zealand; Collins: Auckland, New Zealand, 1976.

32. McDonald, J.H. Regressions. In Handbook of Biological Statistics; Sparky House Publishing: Baltimore, MD, USA, 2014; Volume 2, pp. 173-181.

33. Kreyling, J.; Schweiger, A.H.; Bahn, M.; Ineson, P.; Migliavacca, M.; Morel-Journel, T.; Christiansen, J.R.; Schtickzelle, N.; Larsen, K.S. To replicate, or not to replicate-that is the question: How to tackle nonlinear responses in ecological experiments. Ecol. Lett. 2018, 21, 1629-1638. [CrossRef]

34. Meinertz, J.R.; Greseth, S.L.; Gaikowski, M.P.; Schmidt, L.J. Chronic toxicity of hydrogen peroxide to Daphnia magna in a continuous exposure, flow-through test system. Sci. Total Environ. 2008, 392, 225-232. [CrossRef]

35. Reichwaldt, E.S.; Zheng, L.; Barrington, D.J.; Ghadouani, A. Acute toxicological response of Daphnia and Moina to hydrogen peroxide. J. Environ. Eng. 2011, 138, 607-611. [CrossRef]

36. Wasielak, K. The Influence of Atomic Oxygen on Chemical Properties and Microbial Activity in Aquatic Ecosystem; The University of Warsaw: Warsaw, Poland, 2016.

37. OECD SIDS Initial Assessment Report for SIAM 15-Sodium Carbonate. Available online: https: //hpvchemicals.oecd.org/ui/handler.axd?id=5A6538BE-AA30-4A72-AD1C-906D9B5413BD (accessed on 19 March 2020).

38. Bogart, S.J.; Woodman, S.; Steinkey, D.; Meays, C.; Pyle, G.G. Rapid changes in water hardness and alkalinity: Calcite formation is lethal to Daphnia magna. Sci. Total Environ. 2016, 559, 182-191. [CrossRef]

39. Warne, M.S.D.; Schifko, A.D. Toxicity of laundry detergent components to a freshwater cladoceran and their contribution to detergent toxicity. Ecotoxicol. Environ. Saf. 1999, 44, 196-206. [CrossRef]

40. Geer, T.D.; Kinley, C.M.; Iwinski, K.J.; Calomeni, A.J.; Rodgers, J.H. Comparative toxicity of sodium carbonate peroxyhydrate to freshwater organisms. Ecotoxicol. Environ. Saf. 2016, 132, 202-211. [CrossRef]

41. Pirow, R.; Wollinger, F.; Paul, R.J. The sites of respiratory gas exchange in the planktonic crustacean Daphnia magna: An in vivo study employing blood haemoglobin as an internal oxygen probe. J. Exp. Biol. 1999, 202, 3089-3099. [PubMed]

42. Broönmark, C.; Hansson, L.-A. The Biology of Lakes and Ponds; Oxford University Press: Oxford, UK, 2018.

43. Pirow, R.; Buchen, I. The dichotomous oxyregulatory behaviour of the planktonic crustacean Daphnia Magna. J. Exp. Biol. 2004, 207, 683-696. [CrossRef] [PubMed] 
44. Ebert, D. Ecology, Epidemiology, and Evolution of Parasitism in Daphnia; National Library of Medicine (US): Bethesda, MD, USA; National Center for Biotechnology Information: Basel, Switzerland, 2004.

45. Pirow, R.; Wollinger, F.; Paul, R.J. The importance of the feeding current for oxygen uptake in the water flea Daphnia magna. J. Exp. Biol. 1999, 202, 553-562. [PubMed]

46. Burns, C.W. Relation between filtering rate, temperature, and body size in four Species of Daphnia. Limnol. Oceanogr. 1969, 14, 693-700. [CrossRef]

47. Egloff, D.A.; Palmer, D.S. Size relations of the filtering area of two Daphnia species. Limnol. Oceanogr. 1971, 16, 900-905. [CrossRef]

48. Crafton, E.A.; Cutright, T.J.; Bishop, W.M.; Ott, D.W. Modulating the effect of iron and total organic carbon on the efficiency of a hydrogen peroxide-based algaecide for suppressing cyanobacteria. Water Air Soil Pollut. 2019, 230, 56. [CrossRef]

49. Kędzierska, A. Methods of Mitigation of Cyanobacterial Blooms Basing on Various-Scale Experiments. Master's Thesis, University of Warsaw, Warsaw, Poland, 2016.

(C) 2020 by the authors. Licensee MDPI, Basel, Switzerland. This article is an open access article distributed under the terms and conditions of the Creative Commons Attribution (CC BY) license (http://creativecommons.org/licenses/by/4.0/). 